Article

\title{
Environmental Regulation and Corporate Financing-Quasi-Natural Experiment Evidence from China
}

\author{
Xinghe Liu ${ }^{1}$, Enxian Wang ${ }^{2, *}$ and Danting Cai ${ }^{3}$ \\ 1 School of Management, Xiamen University, Xiamen 361005, China; xingheliu@xmu.edu.cn \\ 2 Institute for Financial and Accounting Studies, Xiamen University, Xiamen 361005, China \\ 3 School of Hotel and Tourism Management, the Hong Kong Polytechnic University, Hong Kong, China; \\ danting.cai@connect.polyu.hk \\ * Correspondence: wangexian@stu.xmu.edu.cn; Tel.: +86-177-5061-1133
}

Received: 5 October 2018; Accepted: 31 October 2018; Published: 2 November 2018

\begin{abstract}
The Environmental Protection Law, which includes 70 articles and major changes in six aspects compared to the old law, is called in Chinese society the new Environment Protection Law. When the law was implemented in 2014, it was an important event in China that could be seen as a natural experiment. Based on a difference-in-differences model, this paper considers all of the listed heavily polluting enterprises between 2011 and 2016 as the experimental group and all of the other firms in the same industries listed on the Chinese stock market as the control group and examines the impact of the new Environmental Protection Law on the corporate financing of heavily polluting enterprises and its mechanisms. The results show that the strict environmental law caused Chinese listed enterprises to face higher environmental regulation costs, public pressure and environmental litigation. The financing capacity of heavily polluting enterprises has dropped significantly, especially in areas with higher regulatory intensity. Furthermore, since the new Environmental Protection Law was established, overinvestment by China's heavily polluting enterprises has been significantly inhibited, and the decline in financing capacity exerts a mediating effect. The ultimate economic consequences of the new Environmental Protection Law are to decrease the corporate value of heavily polluting industries.
\end{abstract}

Keywords: environmental regulation; regulatory intensity; corporate financing; corporate value; heavily polluting enterprises

\section{Introduction}

Environmental problems have become increasingly prominent in China due to the rapid development of the economy and society. Environmental regulation refers to the sum of policies and measures formulated and implemented for the purpose of environmental protection. According to the degree of coercion of policy instruments, they can be divided into three categories: direct regulation (standards, orders and controls); economic instruments (taxes, tradable emissions permits, etc.); and "soft" means (voluntary industry agreements, environmental programs certifications, etc.) [1], among which the introduction of a law marks the highest level of environmental regulation.

The original Environmental Protection Law (1989) had an undeniable effect on protecting resources and the environment, but the law was implemented more than 20 years ago, and major changes have occurred in China's economic system and societal structure since then. Clearly, the law was lagging behind social realities, seriously restricting China's rational use and effective protection of resources and the environment. Millions of people thus called for improvement of the Environmental Protection Law, and China began enforcing a newly amended Environmental 
Protection Law. From 2012, the Standing Committee of the National People's Congress conducted four deliberations of the revised draft of this law, and in April 2014, the new Environmental Protection Law was officially adopted. The new environmental protection law has been hailed as the strictest environmental law in history.

The impact of environmental regulation on enterprise performance remains unclear. In the literature, there are three theoretical disputes: the "Compliance Cost Theory", "Porter Hypothesis" and "Uncertainty Hypothesis".

Compliance cost theory argues that environmental regulation increases production costs and reduces productive investment by enterprises, leading to declining manufacturing performance [2-4]. However, the Porter hypothesis questions the above theory and argues that appropriate environmental regulation can motivate enterprises to develop technological innovation and promote enterprise performance [5,6]. In addition to the two above theories, there is another perspective on the current environmental regulation of enterprise performance research: the "Uncertainty Hypothesis". This hypothesis states that there are many uncertainties between environmental regulation and corporate performance, and the timing of implementing environmental regulation is also different, leading to uncertainty in the impact of environmental regulation on corporate performance $[7,8]$.

Enterprise value is a comprehensive assessment of the market economy system and is affected by many factors. The factors affecting corporate value are mainly divided into four aspects: capital structure, enterprise performance, business strategy and corporate governance structure [9-12]. The corporate governance structure can be divided into three categories: shareholder governance, creditor governance and stakeholder governance. However, this paper starts from the perspective of creditors in the corporate governance structure and studies the changes in corporate financing behaviors and investment behaviors brought about by environmental regulations and ultimately the changes in the value of enterprises. It helps us to understand how the legal policies of the mesoenvironment affect the behavior of microenterprises and provide an empirical and theoretical basis for regulators to formulate policies. The focus of this paper is not to prove which view is more reasonable but instead to address corporate financing ability after environmental regulation changes, investigating whether corporate financing ability changes, whether this change affects the investment behavior of the company, and whether it affects the value of the company.

This article treats the new Environmental Protection Law entering into force as an event, selects the China stock market's list of heavily polluting enterprises as a sample, and empirically tests the impact of the "new law" on the financing behaviors of heavily polluting enterprises. Existing research results have found that the promulgation of the new Environmental Protection Law brought higher regulation costs to enterprises and impacted the stock prices of heavily polluting enterprises $[13,14]$. This paper considers corporate financing: the study hypothesizes that the new Environmental Protection Law could negatively affect the financing ability of heavily polluting enterprises through risk and regulatory effects. This impact on corporate financing is mainly reflected in heavily polluting enterprises receiving less debt financing and shorter debt maturities; this phenomenon is more significant in regions under higher regulatory intensity. Further investigation also finds that since the promulgation of the new Environmental Protection Law, overinvestment by China's heavily polluting enterprises has been significantly inhibited. Therefore, the conclusions are of strong theoretical and practical significance, especially to the research on this unique sample of heavily polluting enterprises. By exploring the impact of environmental regulation on corporate financing behavior from the perspective of environmental regulation, this article offers supplementary research on the factors influencing corporate financing. In addition, the conclusions improve understanding of the financing behavior of heavily polluting enterprises under China's environmental governance. Finally, because the paper uses the promulgation of a new law as an exogenous natural experiment, endogeneity problems are greatly alleviated, and this dynamic study helps to prove the assumptions.

The remainder of this paper is organized as follows. Section 2 describes the institutional background. Section 3 outlines the theoretical analysis and research hypotheses. Section 4 describes 
the research methods, which involve sample selection, data collection, model development and the definition of variables, while the empirical results and analysis are presented in Section 5. Section 6 summarizes and concludes with suggestions for future research.

\section{Institutional Background}

The decree of the President of the People's Republic of China No.9, by Chinese President Xi Jinping on 24 April 2014, approved the new Environmental Protection Law. China formally began implementing the updated Environmental Protection Law ("the China EPL") on 1 January 2015. This time was the first that China's fundamental environmental protection statute had been revised since it was first promulgated in 1989. There are usually three hearings of a law in China before voting, but after the first revision of the Environmental Protection Law (Draft) by the Standing Committee of the National People's Congress of China, the draft underwent four deliberations before being finalized. This process reflects that environmental issues are also current social issues in China. The law increased the responsibility of enterprises, and all aspects of violations receive greater punishment; law experts refer to this law as "the strictest environmental law in history". The revised new Environmental Protection Law further clarified the government's responsibility for the supervision and management of environmental protection, such as clearly defining the ecological red line, controlling the total pollutant load, assessing environmental impacts, monitoring and auditing the environment, establishing a joint administrative area approach to prevention and control, increasing the responsibility of enterprises to prevent and control pollution, increasing legal sanctions on environmental violations, systematically regulating government and enterprise behavior in disclosing environmental information and encouraging public participation in supervising environmental protection systems.

The newly revised Environmental Protection Law has three important features. The first is the basic concept of ecological civilization, protection priorities, public participation, and the coordination and integration of economic, social and environmental aspects. The second consists of the many drastic legal provisions: penalties by day (Article 59), seizure (Article 25), regional sanctions (Article 44) and the blacklist system (Article 54). The third is that the system has been further perfected. In other words, the new Environmental Protection Law has great significance for protecting and improving the environment, promoting the construction of an ecological civilization, and promoting sustainable economic and social development. Since the promulgation of the new Environmental Protection Law in 2014, environmental protection departments at all levels have transferred 2080 cases of suspected environmental crimes to public security organs, twice the sum of the previous 10 years. According to the new Environmental Protection Law, Article 59, Article 25 and Article 44, the numbers of penalties filed from 2015 to 2017 were 11,776, 22,730 and 39,593, respectively. The amounts of punishment were 4.25 billion yuan, 6.63 billion yuan, and 11.58 billion yuan, respectively, with annual growth rates of $34 \%, 56 \%$, and $74.6 \%$. As a concrete example, before 2013 , the highest penalty for illegal sewage disposal by heavily polluting enterprises was only 200,000 yuan, but after the new Environmental Protection Law came into effect, according to penalty by day (Article 59), if the heavily polluting enterprise is within 100 days after the deadline for treatment and if the pollution control is still not completed, the penalty amount will be 20 million yuan, and according to seizure (Article 25), the person in charge of the polluting enterprise can even be arrested for alleged environmental violations. This punishment was not possible under the previous environmental protection law. Therefore, after the introduction of the new Environmental Protection Law, the pollution behaviors of heavily polluting enterprises are greatly affected compared with those of nonpolluting enterprises.

\section{Theoretical Analysis and Research Hypothesis}

(1) Environmental regulation and corporate financing

After the reform and opening up, China underwent rapid economic growth. With this economic growth came an increase in environmental awareness in China and among the media, along with 
increased attention to environmental protection and pollution. At the same time, the Chinese Ministry of Environmental Protection was actively guiding the environmental protection behaviors of enterprises. The improvement of people's standard of living was accompanied by an awareness of the increasing importance of environmental protection. Protecting the environment became a "stable" and "influential" social norm [15]. Social norms guide and strengthen the beliefs and values of people, thereby affecting decision-making behaviors across society and influencing the evolution of social institutions, ultimately changing the allocation of social resources [16]. The promulgation of the new Environmental Protection Law represents a further upgrade of the social system since it allows the government, the market and the media to more easily supervise and sanction heavily polluting enterprises.

The financing methods for Chinese enterprises are mainly divided into equity financing and debt financing. To maintain and stabilize the development of the Chinese capital market, the Chinese government has strict controls on equity financing. Therefore, enterprises cannot directly and effectively obtain equity financing from the capital market in the short term. Therefore, the main external financing channel for enterprises in China currently remains debt financing, which is mainly based on indirect financing methods, such as bank loans. Previous studies based on signaling theory have suggested that information disclosure quality, internal controls, corporate governance, media regulation, and political connections have impacts on corporate financing. However, the credit decision of the creditor is closely related to its risk perception; if the creditor's risk perception is high, the financing ability of the enterprise decreases, and industry characteristics are precisely the type of important factor that can affect the creditor's risk perception. Schneider [17] reported that the debt capital market considers high polluting enterprises to be high-risk investments because enterprises with poor environmental performance could face major environmental liabilities in the future; therefore, creditors would require a modest increase in the rate of return to compensate for environmental risks.

Credit approval among Chinese banks is based on three principles: security, liquidity, and profitability. The principle of security requires banks and other financial institutions to attempt to avoid risk and the loss of credit funds in the process of operating a credit business. After the promulgation of the new Environmental Protection Law, heavily polluting enterprises fell under tremendous pressure from increased public awareness, investment risks, and environmental litigation risks. Liu [18] argued that after the PM2.5 explosion incident, heavily polluting enterprises faced greater risks due to increased public pressure, thus reducing the amount of available external financing and requiring them to pay higher financing costs. The PM2.5 explosion incident triggered changes in informal institutions, and the accumulation of informal institutional conflicts forced government authorities to impose stricter controls. The new Environmental Protection Law imposes strict, real-time supervision on polluting enterprises, such as an ordered exit, the suspension of production, and substantial penalties. Stiglitz and Weiss [19] argued that enterprises cannot obtain long-term debt financing when information asymmetry and default risk are high. The environmental problems of heavily polluting enterprises can be easy to conceal because they require substantial professional knowledge, and there is often serious information asymmetry between the creditor and the loan enterprise regarding the environmental performance of the enterprise. If an environmental accident occurs, the enterprise will be severely punished by the government, and this punishment will affect the enterprise's solvency and its ability to pay the debt. An order to suspend business to rectify the situation is sometimes fatal for the enterprise because it can lead to bankruptcy and directly threaten the security of commercial banks' credit assets. Given the safety principle, after the promulgation of the new Environmental Protection Law, heavily polluting enterprises would receive less debt financing.

On 24 February 2012, the China Banking Regulatory Commission announced the "Green Credit Guidelines", which required a combination of regulatory and industrial policies. The aim of these guidelines is to promote green credit banking among financial institutions, with green credit serving as the starting point for economic development. After the promulgation of the new Environmental Protection Law, the original political advantage held by heavily polluting industry disappeared, to be 
replaced by the strict control of the government authorities. It is thus to be expected that the credit market would be affected by the policy and would attempt to avoid allowing "polluted enterprises" to obtain credit funds.

In addition, if Chinese commercial banks disregard public opinion and only focus on profit-seeking, particularly if they approve more debt financing for polluting enterprises, such actions would reflect low social responsibility and would increase environmental damage. If a bank arbitrarily supports the projects of polluting enterprises, it will inevitably damage the bank's reputation by triggering public resentment and deepening distrust in the bank-potentially leading society to condemn its behavior. Sanctions against members who violate social norms are common in China, similar to the "meta-norm" defined by Axelrod [20]. If members of society do not condemn violations of social norms, then they themselves might be the objects of condemnation by other members of society. Hence, based on the above analysis, a hypothesis (H1) is proposed as follows:

Hypothesis 1 (H1): Since the promulgation of the new Environmental Protection Law, the financing capacity of heavily polluting enterprises has dropped significantly.

\section{(2) Environmental regulation, regulatory intensity and corporate debt financing}

China's rapid economic growth over the past three decades has required the sacrifice of environmental quality. However, the new Environmental Protection Law is forcing enterprises to face more severe sanctions for violations of laws and regulations, having improved upon the embarrassing situation wherein enterprises receive low fines when breaking the law. The new Environmental Protection Law adds the resignation system, which increases the local government's legal responsibility for environmental quality control over the administrative region. Since the tax sharing reforms, local governments have launched various competitions around economic development, and a GDP assessment system that neglects the environment can easily lead to environmental resources becoming sacrificed in local governments' "race to the bottom" [21]. Previous studies have shown that corporate debt financing is constrained by the market development level, taxation system, government intervention, level of investor protection and political relations [22-25]. Because uneven economic growth in China's regions has led to different levels of environmental governance by these regions, there are major differences in the formulation of environmental regulation policies by local governments [26,27]. These differences mainly reflect the different levels of intensity needed to resolve the conflict between environmental protection and economic development, in turn leading to impacts from environmental regulation on enterprise behaviors in various regions. Shen and Ma [28] reported that when local governments are under pressure for economic development, the environmental performance of heavily polluting local enterprises is not an important assessment factor in the provision of new debt financing. After the establishment of the new Environmental Protection Law, major cities formulated policies linking environmental governance completion to government performance appraisals. To achieve economic transformation and upgrading, areas with more intense environmental supervision must simultaneously increase the intensity of heavy pollution control, and supervision limits the financing of heavily polluting enterprises and increases their financing threshold. Unlike regions with higher environmental supervision intensity, for areas with low environmental supervision intensity to achieve economic growth, local governments still have strong incentives to lower environmental protection standards, provide convenient financing for heavily polluting enterprises, and even collude with heavily polluting enterprises and condone environmental pollution for high economic returns. Due to the close alignment of interests between local governments and enterprises and because some heavily polluting enterprises are important sources of local fiscal revenues, these enterprises are protected by local governments. As local environmental protection departments and local financial institutions affiliated with local governments are inevitably subject to local government intervention, the Green Credit policy cannot play a role. Therefore, areas with lower environmental supervision intensity and local governments facing growth pressure are likely to 
sacrifice long-term environmental benefits for short-term economic development performance. Hence, based on the above analysis, a hypothesis (H2) is proposed as follows:

Hypothesis 2 (H2): Since the promulgation of the new Environmental Protection Law, the financing capacity of heavily polluting enterprises have decreased significantly in areas with higher environmental regulation intensity.

\section{Research Method}

\subsection{Sample Selection and Data Sources}

This paper mainly studies the impact of the new Environmental Protection Law on heavily polluting industries' financing behaviors, given environmental regulation costs and public pressure. The sample interval is set at 2011-2016. To define heavy-polluting enterprises, the paper utilizes the implementation of the special emission limits for air pollutants issued by the Ministry of Environmental Protection in 2013 (hereafter referred to as the 2013 MEP Notice). The 2013 MEP Notice identifies "three regions and ten clusters" for special measures-the JJJ region, the YRD, the PRD—and the 10 urban "clusters" include 47 prefectural cities in 19 provinces. The emissions limits target enterprises in six industries: thermal power, steel, petrochemicals, cement, nonferrous metals, and chemicals. If the listed enterprise belongs to one of the above six industries and is located in the identified regions or clusters, then it is regarded as a heavily polluting enterprise. According to the Guideline for Industrial Classification of Listed Companies of the China Securities Regulatory Commission, heavily polluting enterprises are in the same category as other industry listed enterprises regarded as non-heavily polluting enterprises. All heavily polluting enterprises are used as the experimental group, and all non-heavily polluting enterprises are used as the control group based on the new Environmental Protection Law event. A further selection is conducted to ensure complete disclosed enterprise data by excluding the following: (1) enterprise samples with poor financial data; (2) ST/PT enterprises; (3) enterprise samples with missing financial data; and to maintain the consistency of the company before and after the event, (4) companies listed after 2014. Ultimately, there are a total of 9378 available observation data points. All of the financial data are collected from the CSMAR Database, and environmental regulation intensity is manually measured based on information disclosed by the Institute of Public and Environmental Affairs (IPE). The study winsorizes the variables at the $1 \%$ level.

\subsection{Model Setting and Definition of Variables}

A difference-in-difference (DID) model is built to verify the proposed hypotheses 1 and 2 . The settings of the DID model are similar to those in Bertrant et al. [29], Ye Qing et al. [30], and Liu and Liu [31]. The DID model can largely avoid endogenous problems: first, the policy is generally exogenous to the microeconomic entity, so there is no reverse causality problem; second, the evaluation of policy effects (such as OLS) under the traditional method is mainly through setting a dummy variable for the occurrence or absence of a policy and then performing regression. In comparison, the model of the DID method is more scientific and can more accurately estimate the policy effect.

The DID model can be expressed as:

$$
\begin{gathered}
\text { Debt }_{i t}=\beta_{0}+\beta_{1} \text { Pollute }_{i}+\beta_{2} \text { Regulation }_{t}+\beta_{3}\left(\text { Pollute } * \text { Regulation }_{i t}+\gamma \text { Control }+\varepsilon_{i i}\right. \\
\text { Long_loan }_{i t}=\beta_{0}+\beta_{1} \text { Pollute }_{i}+\beta_{2} \text { Regulation }_{t}+\beta_{3}\left(\text { Pollute } * \text { Regulation }_{i t}+\gamma \text { Control }+\varepsilon_{i i}\right.
\end{gathered}
$$

In models (1) and (2), Debt $_{i t}$ and Long_loan ${ }_{i t}$ are the dependent variables and measure corporate financing capacity according to the studies by Shen and Ma [28] and Zhu [32]. Pollute $e_{i}$ is a dummy variable assigned a value of 1 for the experimental group and 0 for the control group. $i$ indicates enterprise, and $t$ indicates the year. If the individual $i$ is not implemented by the policy, the effect of the individual $i$ belongs to the control group, and the corresponding Pollute takes a value of 0 . The regulation implements a dummy variable for the policy. Before the policy is implemented, the value 
of Regulation is 0 . After the policy is implemented, the value of Regulation is 1 . Pollute* Regulation is the interaction term between the group dummy variable and the policy implementation dummy variable. In Table 1 the coefficient $\beta 3$ reflects the net effect of policy implementation, which is also the most concerned when we use DID.

Table 1. Description of coefficients.

\begin{tabular}{cccc}
\hline & Before & After & Difference \\
\hline Experimental & $\beta_{0}+\beta_{1}$ & $\beta_{0}+\beta_{1}+\beta_{2}+\beta_{3}$ & $\beta_{2}+\beta_{3}$ \\
Control & $\beta_{0}$ & $\beta_{0}+\beta_{2}$ & $\beta_{2}$ \\
Difference & $\beta_{1}$ & $\beta_{1}+\beta_{3}$ & $\beta_{3}$ \\
\hline
\end{tabular}

The other variables are control variables, including the scale of the company (Size), leverage ratio (Lev), return on assets (Roa), growth opportunity (Growth), independence (Indr), the duality of the chair and CEO (Dual), board size (Board) and controlling shareholder (First).

See Table 2 for a description of the variables.

Table 2. Descriptions of variables.

\begin{tabular}{cc}
\hline Variable & Description \\
\hline Debt & Bank loans, bank loans / final assets at the end of the period \\
Long_loan & Long-term loans, long-term loans / final assets at the end of the period \\
Pollute & 1 for heavily polluting enterprises, 0 for non-heavily polluting enterprises \\
Regulation & 0 for issued during $2011-2013,1$ for issued during 2014-2016 \\
Size & The natural logarithm of the enterprise's assets at the end of the year \\
Lev & Total liabilities/total assets \\
Growth & Net Income/Total assets \\
Roa & (Present sales revenues) - (Past sales revenues sales revenues) \\
Indr & Number of independent directors /Number on board \\
Dual & 1 if chair and CEO are the same person, otherwise 0 \\
Board & Board size \\
Mkt & Marketization index \\
First & Ratio of first shareholders \\
Piti_dum & Pollution Information Transparency Index (PITI), 1 for greater than the median, 0 for otherwise
\end{tabular}

Note: The Pollution Information Transparency Index (PITI) was jointly developed by the Institute of Public and Environmental Affairs (IPE) and the Natural Resources Defense Council (NRDC) in 2009. It was founded after the implementation of "Regulations on the Disclosure of Government Information" and the "Environmental Information Disclosure Measures" (Trial Implementation) by the Ministry of Environmental Protection. The PITI evaluation standard evaluates the annual environmental information for more than 100 cities across the country, provides evaluation results and scores, and ranks them.

\section{Empirical Results and Analysis}

\subsection{Descriptive Statistics}

Table 3 shows the distribution of heavily polluting enterprises across the provinces in China. It can be clearly observed that in areas with high economic development and a high degree of marketization, such as Shanghai, Beijing, Guangdong, Shandong, Jiangsu and Zhejiang, their heavily polluting enterprise numbers are much greater than those in other areas, which is generally consistent with the distribution of the number of Chinese listed entrepreneurs, so there is no selective bias. 
Table 3. Distribution across provinces of heavily polluting enterprises.

\begin{tabular}{cccccccc}
\hline Province & Freq. & Percent & Cum. & Province & Freq. & Percent & Cum. \\
\hline Shanghai & 143 & 4.88 & 4.88 & Hebei & 89 & 3.04 & 66.38 \\
Yunnan & 70 & 2.39 & 7.27 & Henan & 128 & 4.37 & 70.75 \\
Inner Mongolia & 66 & 2.25 & 9.52 & Zhejiang & 231 & 7.88 & 78.63 \\
Beijing & 137 & 4.68 & 14.2 & Hainan & 19 & 0.65 & 79.28 \\
Jilin & 44 & 1.5 & 15.7 & Hubei & 90 & 3.07 & 82.35 \\
Sichuan & 152 & 5.19 & 20.89 & Hunan & 99 & 3.38 & 85.73 \\
Tianjin & 11 & 0.38 & 21.26 & Gansu & 45 & 1.54 & 87.27 \\
Ningxia & 38 & 1.3 & 22.56 & Fujian & 96 & 3.28 & 90.55 \\
Anhui & 148 & 5.05 & 27.61 & Tibet & 12 & 0.41 & 90.96 \\
Shandong & 257 & 8.77 & 36.38 & Guizhou & 31 & 1.06 & 92.01 \\
Shanxi & 71 & 2.42 & 38.81 & Liaoning & 94 & 3.21 & 95.22 \\
Guangdong & 268 & 9.15 & 47.95 & Chongqing & 37 & 1.26 & 96.48 \\
Guangxi & 46 & 1.57 & 49.52 & Shaanxi & 41 & 1.4 & 97.88 \\
Xinjiang & 71 & 2.42 & 51.95 & Qinghai & 21 & 0.72 & 98.6 \\
Jiangsu & 277 & 9.45 & 61.4 & Heilongjiang & 41 & 1.4 & 100 \\
Jiangxi & 57 & 1.95 & 63.34 & Total & 2930 & 100 & \\
\hline
\end{tabular}

Based on the data comparing the experimental group and the control group, Panel A data are shown in Table 4, including 2937 samples of heavily polluting enterprises belonging to 12 major industries (The 12 industries are: oil and gas exploration (B07); ferrous mining (B08); nonferrous mining (B09); petroleum processing; paper and paper products (C22); coking and nuclear fuel (C25); chemical raw materials and chemical manufacturing (C26); chemical fiber manufacturing (C28); rubber and plastic products (C29); nonmetallic mineral products (C30); ferrous metal smelting and rolling processing (C31); nonferrous metals smelting and rolling processing (C32); electricity, thermal production and supply (D44)), which is approximately $13 \%$ of the 90 major industries classified by the CSRC. It is close to the actual overall industry distribution percentage of listed enterprises for China's heavily polluting industries and is the best and most typically representative. Panel B lists the industry distribution of the control group for a total of 24 major categories of industries. 
Table 4. Industrial distribution.

\begin{tabular}{|c|c|c|c|c|c|c|c|c|c|c|c|c|c|c|}
\hline \multirow{2}{*}{$\begin{array}{l}\text { Panel A: } \\
\text { Nnindcd }\end{array}$} & \multicolumn{14}{|c|}{ Industrial Distribution of Experimental Group Samples } \\
\hline & B07 & B08 & B09 & $\mathrm{C} 22$ & $\mathrm{C} 25$ & $\mathrm{C} 26$ & $\mathrm{C} 28$ & $\mathrm{C} 29$ & $\mathrm{C} 30$ & C31 & C32 & D44 & & Total \\
\hline Freq. & 26 & 16 & 117 & 156 & 96 & 906 & 130 & 258 & 398 & 171 & 303 & 360 & & 2937 \\
\hline Percent & 0.89 & 0.54 & 3.98 & 5.31 & 3.27 & 30.85 & 4.43 & 8.78 & 13.55 & 5.82 & 10.32 & 12.26 & & 100 \\
\hline Panel B: & \multicolumn{14}{|c|}{ Industrial Distribution of Control Group Samples } \\
\hline Nnindcd & B06 & B11 & $\mathrm{C} 13$ & $\mathrm{C} 14$ & $\mathrm{C} 15$ & $\mathrm{C} 17$ & $\mathrm{C} 18$ & C19 & $\mathrm{C} 20$ & $\mathrm{C} 21$ & $\mathrm{C} 23$ & $\mathrm{C} 24$ & $\mathrm{C} 27$ & \\
\hline Freq. & 146 & 42 & 199 & 132 & 191 & 221 & 153 & 32 & 44 & 28 & 40 & 54 & 807 & \\
\hline Percent & 2.27 & 0.65 & 3.09 & 2.05 & 2.97 & 3.43 & 2.38 & 0.50 & 0.68 & 0.43 & 0.62 & 0.84 & 12.53 & \\
\hline Nninded & $\mathrm{C} 33$ & C 34 & C35 & C36 & $\mathrm{C} 37$ & C38 & C 39 & $\mathrm{C} 40$ & $\mathrm{C} 41$ & $\mathrm{C} 42$ & C43 & D45 & $\mathrm{D} 46$ & Total \\
\hline Freq. & 235 & 497 & 693 & 426 & 182 & 819 & 1155 & 124 & 92 & 7 & 1 & 48 & 73 & 6441 \\
\hline Percent & 3.65 & 7.72 & 10.76 & 6.61 & 2.83 & 12.72 & 17.93 & 1.93 & 1.43 & 0.11 & 0.02 & 0.75 & 1.13 & 100 \\
\hline
\end{tabular}


The descriptive statistics for the whole sample are shown in Table 5. The sample is not significantly different from the average for all of China's listed companies in terms of size, debt ratio and risk; this outcome indicates that the sample has a certain overall representativeness, and the statistical characteristics of the data are basically consistent with the previous literature [31,32]. The mean of Pollute is 0.310 , indicating that the proportion of heavily polluting enterprises in the sample reached $31 \%$. The mean of Debt is 0.16 , its max is 0.64 , and its min is 0 . The mean of Long_loan is 0.04 , its max is 0.38 , and its $\min$ is 0 . There are three possible explanations: first, some listed companies have ample cash and implement a zero-debt financial policy; second, some enterprises are facing severe financing constraints and cannot achieve financing through external long-term loans; or third, a phenomenon exists among Chinese corporations that long-term investments are made with short-term financing [33]. The mean of Lev is 0.42 , its min is 0.05 , and its max is 0.95 . The mean of Dual is 0.270 , which shows that $27 \%$ of enterprises have a dual CEO/chair. The mean of First is 0.37 , showing that the single large shareholder phenomenon in China's listed enterprises is particularly obvious. The mean of Indr is 0.37, showing that the proportion of independent directors in China's enterprises meets the one-third standard of most listed companies, in conformity with the CSRC requirement (On 16 August 2001, the "Guiding Opinions on Establishing an Independent Director System in Listed Companies", issued by the China Securities Regulatory Commission, noted that before 30 June 2002, the board of directors should include at least two independent members: "Directors: Before 30 June 2003, the board of directors of a listed company shall include at least one-third independent directors"). The marketization index min is 2.53 , and its max is 10.46 , with a standard deviation is 1.78 , showing that the level of marketization development in China is not balanced, and the differences between regions are large.

Table 5. Descriptive statistics of the whole sample.

\begin{tabular}{ccccccccc}
\hline Variable & $\mathbf{N}$ & Mean & sd & p25 & p50 & p75 & Min & Max \\
\hline Pollute & 9378 & 0.31 & 0.46 & 0 & 0 & 1 & 0 & 1 \\
Debt & 9378 & 0.16 & 0.15 & 0.03 & 0.13 & 0.26 & 0 & 0.64 \\
Long_loan & 9378 & 0.04 & 0.07 & 0 & 0 & 0.05 & 0 & 0.38 \\
Size & 9378 & 21.98 & 1.23 & 21.11 & 21.8 & 22.65 & 19.56 & 25.77 \\
Lev & 9378 & 0.42 & 0.21 & 0.250 & 0.41 & 0.58 & 0.05 & 0.95 \\
Roa & 9378 & 0.04 & 0.05 & 0.01 & 0.03 & 0.06 & -0.18 & 0.20 \\
Growth & 9378 & 0.06 & 0.26 & -0.04 & 0.08 & 0.19 & -1.04 & 0.76 \\
Dual & 9378 & 0.27 & 0.44 & 0 & 0 & 1 & 0 & 1 \\
Board & 9378 & 8.71 & 1.69 & 8 & 9 & 9 & 5 & 15 \\
Indr & 9378 & 0.37 & 0.05 & 0.33 & 0.33 & 0.43 & 0.33 & 0.57 \\
Mkt & 9309 & 7.810 & 1.780 & 6.540 & 7.930 & 9.350 & 2.530 & 10.46 \\
First & 9378 & 0.35 & 0.15 & 0.23 & 0.33 & 0.45 & 0.09 & 0.75 \\
Piti_dum & 7000 & 0.60 & 0.49 & 0 & 1 & 1 & 0 & 1 \\
\hline
\end{tabular}

\subsection{Analysis of Regression Results}

\subsubsection{Empirical Results from the Financing Ability Analysis}

Panels A and B of Table 6 compare the changes in the financing ability of the experimental group and the control group before and after environmental regulation. The data show that the promulgation of the new Environmental Protection Law has a negative net effect on the experimental group sample. For the samples in the experimental group in Panel A, after environmental regulation, the financing ability of the heavily polluting enterprises decreased significantly, and the mean and median of Debt and Long_loan decreased significantly. However, for the Panel B sample, only the mean of Debt showed a statistically significant decrease, but the decrease was only 0.007 , which was much smaller than that of the experimental group, and there was no statistically significant decrease in the median. The mean and median test of the group indicates that environmental regulation has a certain negative 
net effect on the financing ability of heavily polluting enterprises, but multiple subsequent regressions are still needed to obtain more stable conclusions.

Table 6. Two-group testing of the difference of the means.

\begin{tabular}{ccccccccc}
\hline Panel A: Experimental & \multicolumn{3}{c}{ Before Regulation } & \multicolumn{3}{c}{ After Regulation } & MeanDiff & MedianDiff \\
\hline Variables & $\mathbf{N}$ & Mean & Median & $\mathbf{N}$ & Mean & Median & MeanDiff & Chi2 \\
Debt & 1438 & 0.249 & 0.237 & 1499 & 0.218 & 0.201 & $0.031^{* * *}$ & $13.217^{* * *}$ \\
Long_loan & 1438 & 0.068 & 0.02 & 1499 & 0.057 & 0.017 & $0.011^{* * *}$ & 0.213 \\
\hline Panel B: control & \multicolumn{3}{c}{ Before regulation } & \multicolumn{3}{c}{ After regulation } & MeanDiff & MedianDiff \\
\hline Variables & $\mathbf{N}$ & Mean & Median & $\mathbf{N}$ & Mean & Median & MeanDiff & Chi2 \\
Debt & 3083 & 0.137 & 0.096 & 3358 & 0.13 & 0.095 & $0.007^{* *}$ & 0.056 \\
Long_loan & 3083 & 0.026 & 0 & 3358 & 0.027 & 0 & -0.001 & $33.434^{* * *}$ \\
\hline
\end{tabular}

Note: ${ }^{* * *},{ }^{* *}$ and ${ }^{*}$ represent significance levels of $1 \%, 5 \%$ and $10 \%$, respectively. MeanDiff represents the difference of means, and MedianDiff represents Chi-square value.

\subsubsection{Empirical Results from the Environmental Regulation and Corporate Financing Analysis}

After the establishment of the new Environmental Protection Law, heavily polluting enterprises experienced greater social pressure and government regulation, and any corporate violations implied an increased risk of loan default. As their main debt providers, banks could also undertake greater controls and constraints, making it possible to provide less debt financing to heavily polluting enterprises. To test this hypothesis, Table 7 reports the DID regression results for the full sample. This paper uses Debt and Long_loan to represent the financing ability of enterprises, mainly focusing on the changes in financing ability before and after environmental regulation. The article is mainly concerned with the coefficient of Pollute_Regulation. If the coefficient is significantly negative, it directly indicates that environmental pollution has a negative net effect on heavily polluting enterprises. The explained variables of columns (1) and (2) are Debt, and the explained variables of columns (3) and (4) are Long_loan. No control variables are added to columns (1) and (3), and the enterprise characteristics are added as control variables in columns (2) and (4). In column (1), no control variables are added, and Pollute_Regulation is negatively significant at the $1 \%$ level, while in column (3), the Pollute_Regulation coefficient is also significantly negative at the $1 \%$ level. In columns (2) and (4), after adding the control variables, the regression results of Pollute_Regulation are still negatively significant at the 5 and $1 \%$ levels, respectively. The coefficients are -0.01 and -0.007 , respectively. The economic significance is that the heavily polluting enterprises (experimental group) are fewer than the non-heavily polluting enterprises (control group). Since the new Environmental Protection Law, bank loans (Debt) decreased by $1 \%$, and long-term borrowing (Long_loan) decreased by $0.7 \%$. Compared with the model before the control variable is added, the R-squared correction is significantly improved. After the new Environmental Protection Law, the financing capacity of heavily polluting enterprises was significantly reduced, proving Hypothesis 1 of this study. In terms of other coefficients, the researchers observed that the company size, the leverage level, the company's growth rate and the company's financing ability are significantly positively correlated, and before and after regulation, the first shareholder ratio and the enterprise financing capacity are significantly negatively correlated. Heavily polluting enterprises tend to have a larger asset scale and higher asset-liability ratios and growth rates. These findings are consistent with existing studies [34]. When banks face the highly asymmetric information of the credit market, the heavily polluting enterprises with the aforementioned good characteristics become their "quality customers" and have stronger financing ability than the control group. There is a general phenomenon connected to having a single large holder in China's market, and large shareholders of these types of enterprises are prone to infringing upon the rights of small and medium shareholders and creditors, gaining control and private benefits and inflicting higher agency costs [35]; therefore, having a single large shareholder is negatively correlated with corporate financing. 
Table 7. Environmental regulation and corporate financing.

\begin{tabular}{|c|c|c|c|c|}
\hline & (1) & (2) & (3) & (4) \\
\hline & Debt & Debt & Long_loan & Long_loan \\
\hline Pollute & $\begin{array}{c}0.112 * * * \\
(24.05)\end{array}$ & $\begin{array}{l}0.052 * \\
(1.65)\end{array}$ & $\begin{array}{c}0.041^{* * *} \\
(18.96)\end{array}$ & $\begin{array}{l}-0.016 \\
(-0.92)\end{array}$ \\
\hline Regulation & $\begin{array}{c}-0.007^{*} \\
(-1.86)\end{array}$ & $\begin{array}{c}-0.017^{* * *} \\
(-4.47)\end{array}$ & $\begin{array}{l}0.001 \\
(0.50)\end{array}$ & $\begin{array}{l}-0.003 \\
(-1.40)\end{array}$ \\
\hline Pollute_Regulation & $\begin{array}{c}-0.024^{* * *} \\
(-3.69)\end{array}$ & $\begin{array}{c}-0.010 * * \\
(-2.27)\end{array}$ & $\begin{array}{c}-0.011^{* * *} \\
(-3.77)\end{array}$ & $\begin{array}{c}-0.007^{* * *} \\
(-2.89)\end{array}$ \\
\hline Size & & $\begin{array}{c}0.006^{* * * *} \\
(5.15)\end{array}$ & & $\begin{array}{c}0.012^{* * *} \\
(19.76)\end{array}$ \\
\hline Lev & & $\begin{array}{c}0.469 * * * \\
(75.69)\end{array}$ & & $\begin{array}{c}0.088^{* * *} \\
(25.11)\end{array}$ \\
\hline Roa & & $\begin{array}{c}-0.348^{* * *} \\
(-15.49)\end{array}$ & & $\begin{array}{c}-0.099 * * * \\
(-7.75)\end{array}$ \\
\hline Growth & & $\begin{array}{c}0.014 * * * \\
(3.27)\end{array}$ & & $\begin{array}{c}0.009^{* * *} \\
(3.63)\end{array}$ \\
\hline Dual & & $\begin{array}{c}0.008^{* * *} \\
(3.35)\end{array}$ & & $\begin{array}{l}-0.002 \\
(-1.24)\end{array}$ \\
\hline Board & & $\begin{array}{l}0.001 * \\
(1.91)\end{array}$ & & $\begin{array}{c}-0.001^{* * *} \\
(-2.95)\end{array}$ \\
\hline Indr & & $\begin{array}{l}0.048^{* *} \\
(2.21)\end{array}$ & & $\begin{array}{l}-0.019 \\
(-1.54)\end{array}$ \\
\hline First & & $\begin{array}{c}-0.021^{* * *} \\
(-2.85)\end{array}$ & & $\begin{array}{l}-0.007^{*} \\
(-1.76)\end{array}$ \\
\hline Mkt & & $\begin{array}{l}-0.001 \\
(-1.30)\end{array}$ & & $\begin{array}{c}-0.003^{* * *} \\
(-9.60)\end{array}$ \\
\hline Year\&Industry & & Control & & Control \\
\hline _cons & $\begin{array}{c}0.137^{* * *} \\
(51.80)\end{array}$ & $\begin{array}{c}-0.154^{* * *} \\
(-5.87)\end{array}$ & $\begin{array}{c}0.026^{* * *} \\
(21.39)\end{array}$ & $\begin{array}{c}-0.194^{* * *} \\
(-13.10)\end{array}$ \\
\hline $\mathrm{N}$ & 9378.000 & 9309.000 & 9378.000 & 9309.000 \\
\hline r2_a & 0.094 & 0.617 & 0.056 & 0.409 \\
\hline
\end{tabular}

Note: ${ }^{* * *}, * *$ and ${ }^{*}$ represent significance levels of $1 \%, 5 \%$ and $10 \%$, respectively.

\subsubsection{Environmental Regulation Intensity and Corporate Financing Analysis}

Columns (1) to (4) of Table 8 show the impacts of different areas of regulatory intensity on corporate financing after environmental regulation. Columns (1) and (2) represent the effects of the intensity of supervision on the scale of financing of the enterprise. The research finds that the coefficient of Pollute_Regulation in the group with high regulatory intensity is -0.011 and is significant at the $10 \%$ level; the coefficient of the group with low regulatory intensity is -0.007 , but it is not significant, showing that in the heavily polluting enterprises with high supervision intensity, compared with non-heavily polluting enterprises (control group), bank loans (Debt) decreased by $1.1 \%$ after the promulgation of the new Environmental Protection Law. In terms of statistical significance and economic significance, after the promulgation of the new Environmental Protection Law, enterprises with higher regulatory intensity received less debt financing. Columns (3) and (4) test the maturity structure of debt financing. The coefficient of Pollute_Regulation in the group with high regulatory intensity is -0.011 and is significant at the $5 \%$ level; in the group with low regulatory intensity, the coefficient is -0.003 but is not significant, showing that in heavily polluting enterprises with high supervision intensity, compared with non-heavily polluting enterprises (control group), the debt maturity (Long_loan) decreased by 1.1\% after the promulgation of the new Environmental Protection Law. In terms of statistical significance and economic significance, after the implementation of the new Environmental Protection Law, enterprises with higher regulatory intensity experienced a shorter time 
to debt maturity. In general, after the promulgation of the new Environmental Protection Law, heavily polluting enterprises in areas with high regulatory intensity have faced more regulatory pressure and compliance requirements, and areas with high regulatory intensity are paying more attention to the balance between economic development and environmental protection. Credit institutions have implemented a more thorough green credit policy for heavily polluting enterprises in high regulatory intensity regions, for which heavily polluting enterprises in the region have paid higher costs in debt financing. The empirical results support Hypothesis 2.

Table 8. Environmental regulation intensity and corporate financing.

\begin{tabular}{|c|c|c|c|c|}
\hline & (1) & (2) & (3) & (4) \\
\hline & High & Low & High & Low \\
\hline & Debt & Debt & Long_loan & Long_loan \\
\hline Pollute & $\begin{array}{l}0.034 \\
(1.20)\end{array}$ & $\begin{array}{c}0.060 * * \\
(2.36)\end{array}$ & $\begin{array}{c}0.058^{* * *} \\
(3.60)\end{array}$ & $\begin{array}{l}-0.021 \\
(-1.45)\end{array}$ \\
\hline Regulation & $\begin{array}{c}-0.021 * * * \\
(-3.23)\end{array}$ & $\begin{array}{c}-0.014^{* *} \\
(-1.98)\end{array}$ & $\begin{array}{l}-0.002 \\
(-0.48)\end{array}$ & $\begin{array}{l}-0.005 \\
(-1.26)\end{array}$ \\
\hline Pollute_Regulation & $\begin{array}{l}-0.011^{*} \\
(-1.70)\end{array}$ & $\begin{array}{l}-0.012 \\
(-1.46)\end{array}$ & $\begin{array}{c}-0.011^{* * *} \\
(-3.02)\end{array}$ & $\begin{array}{l}-0.003 \\
(-0.70)\end{array}$ \\
\hline Size & $\begin{array}{c}0.006^{* * *} \\
(4.03)\end{array}$ & $\begin{array}{c}0.009^{* * *} \\
(4.45) \\
\end{array}$ & $\begin{array}{c}0.012^{* * *} \\
(13.65)\end{array}$ & $\begin{array}{c}0.013^{* * *} \\
(11.54)\end{array}$ \\
\hline Lev & $\begin{array}{c}0.460^{* * *} \\
(50.32)\end{array}$ & $\begin{array}{c}0.430^{* * *} \\
(37.73)\end{array}$ & $\begin{array}{c}0.088^{* * * *} \\
(16.78)\end{array}$ & $\begin{array}{c}0.076^{* * * *} \\
(11.62)\end{array}$ \\
\hline Roa & $\begin{array}{c}-0.333^{* * *} \\
(-9.83)\end{array}$ & $\begin{array}{c}-0.415^{* * *} \\
(-9.92)\end{array}$ & $\begin{array}{c}-0.099 * * * \\
(-5.13)\end{array}$ & $\begin{array}{c}-0.111^{* * *} \\
(-4.62)\end{array}$ \\
\hline Growth & $\begin{array}{l}0.004 \\
(0.61) \\
\end{array}$ & $\begin{array}{c}0.034^{* * *} \\
(4.41)\end{array}$ & $\begin{array}{c}0.010^{* * *} \\
(2.94)\end{array}$ & $\begin{array}{c}0.010^{* *} \\
(2.22)\end{array}$ \\
\hline Dual & $\begin{array}{l}0.002 \\
(0.53) \\
\end{array}$ & $\begin{array}{l}0.005 \\
(1.14) \\
\end{array}$ & $\begin{array}{l}-0.004^{* *} \\
(-2.00)\end{array}$ & $\begin{array}{l}-0.004 \\
(-1.40)\end{array}$ \\
\hline Board & $\begin{array}{l}0.002 * * \\
(2.40)\end{array}$ & $\begin{array}{l}0.000 \\
(0.10)\end{array}$ & $\begin{array}{c}-0.001 * * \\
(-2.13)\end{array}$ & $\begin{array}{l}-0.001 \\
(-1.03)\end{array}$ \\
\hline Indr & $\begin{array}{c}0.075^{* *} \\
(2.35) \\
\end{array}$ & $\begin{array}{l}0.060 \\
(1.48) \\
\end{array}$ & $\begin{array}{l}-0.014 \\
(-0.78) \\
\end{array}$ & $\begin{array}{l}-0.011 \\
(-0.49) \\
\end{array}$ \\
\hline First & $\begin{array}{c}-0.041^{* * *} \\
(-3.89)\end{array}$ & $\begin{array}{c}-0.039 * * * \\
(-2.88)\end{array}$ & $\begin{array}{c}-0.014^{* *} \\
(-2.27)\end{array}$ & $\begin{array}{l}-0.015^{*} \\
(-1.92)\end{array}$ \\
\hline Mkt & $\begin{array}{l}-0.001 \\
(-1.11)\end{array}$ & $\begin{array}{l}-0.002 \\
(-1.60)\end{array}$ & $\begin{array}{c}-0.003 * * * \\
(-6.25)\end{array}$ & $\begin{array}{c}-0.005^{* * *} \\
(-6.35)\end{array}$ \\
\hline Year\&Industry & Control & Control & Control & Control \\
\hline _cons & $\begin{array}{c}-0.196^{* * *} \\
(-5.03)\end{array}$ & $\begin{array}{c}-0.202 * * * \\
(-4.21)\end{array}$ & $\begin{array}{c}-0.203 * * * \\
(-9.16)\end{array}$ & $\begin{array}{c}-0.213^{* * *} \\
(-7.69)\end{array}$ \\
\hline $\mathrm{N}$ & 4214.000 & 2786.000 & 4214.000 & 2786.000 \\
\hline r2_a & 0.621 & 0.615 & 0.413 & 0.422 \\
\hline
\end{tabular}

\subsubsection{Further Research}

Environmental Regulation and Investment Efficiency Analysis

The theoretical derivation and empirical tests of this paper have confirmed that environmental regulation reduces the debt financing ability of heavily polluting enterprises and reveals its mechanism. However, the investment behavior of enterprises is closely related to their financing behaviors. Previous research has shown that when enterprises have financing constraints and barriers to obtaining capital, they will reduce their investment opportunities [36]. Therefore, when environmental regulation negatively affects corporate financing behavior, can it further inhibit the excessive investment behaviors of enterprises? Through the mediating effect model, this paper further tests the mediating relationship among environmental regulation, corporate financing and investment efficiency. For the measurement of investment efficiency, this paper draws on the model proposed by Richardson [37]. The specific formula is as follows: 


$$
\begin{aligned}
& \text { invest }_{t} \\
& =\beta_{0}+\beta_{1} \text { growth }_{t-1}+\beta_{2} \text { lev }_{t-1}+\beta_{3} \text { age }_{t-1}+\beta_{4} \text { size }_{t-1}+\beta_{5} \text { return }_{t-1}+\beta_{6} \text { invest }_{t-1} \\
& +\sum \text { industry }+\sum \text { year }+\varepsilon
\end{aligned}
$$

The residual of the model is the measure of enterprise investment efficiency, and the value is positive, indicating that the enterprise has excessive investment compared to the normal investment level; the negative value indicates that the enterprise has insufficient investment.

In this paper, the test procedure for the mediating effect is as follows. First, the effect of environmental regulation on investment efficiency is tested to determine the significance of the Pollute_Regulation coefficient. The second step is to test the influence of environmental regulation on corporate financing (the same as the regression process in Table 8). Finally, environmental regulation, corporate financing variables, and excessive investment variables are simultaneously placed in the regression model to observe the significance and coefficient of the intersection term Pollute_Regulation and to observe the significance of the mediator variables (Debt and Long_loan). If the coefficients are significant, and the absolute value of the coefficient of Pollute_Regulation is less than the absolute value of the coefficient in the first step of regression, it indicates that there are some mediating effects among environmental regulation, corporate financing and investment efficiency. The regression results for the first step are shown in Table 9. In the overinvestment group, the coefficient of Pollute_Regulation is significantly negative. The coefficient is -0.013 , indicating that in the group of heavily polluting enterprises (experimental group), compared to non-heavily polluting enterprises (control group), their overinvesting behavior decreased by $1.3 \%$ since the promulgation of the new Environmental Protection Law. In the underinvestment group, the coefficient of Pollute_Regulation is not significant, indicating that environmental regulation has significantly inhibited overinvestment by heavily polluting enterprises. The second step is verified in Table 8. In the third step, Debt and Long_loan are substituted into the model of the first step. The test results are shown in Table 10. Pollute_Regulation is -0.012 in column (1), is significantly negative at the 10\% level and is less than Pollute_Regulation in Table 8, while the coefficient of the mediating variable Debt is significantly negative, indicating that reducing bank borrowing has a partial mediating effect on inhibiting enterprise investment. The coefficient of Pollute_Regulation in column (2) of Table 9 is -0.009 but is not significant, and the coefficient of the mediation variable Long_loan is significantly negative, indicating that the reduction in long-term borrowing has a complete, mediating effect on inhibiting enterprise investment.

Table 9. Environmental regulation and investment efficiency.

\begin{tabular}{ccc}
\hline & $\mathbf{( 1 )}$ & $\mathbf{( 2 )}$ \\
\cline { 2 - 3 } & Overinvest & Underinvest \\
\hline \multirow{2}{*}{ Pollute } & -0.035 & 0.007 \\
& $(-0.40)$ & $(0.88)$ \\
\hline \multirow{2}{*}{ Regulation } & $0.025^{* * *}$ & $0.004^{* * *}$ \\
Pollute_Regulation & $(3.69)$ & $(2.86)$ \\
\hline \multirow{2}{*}{ Size } & $-0.013^{* *}$ & 0.002 \\
& $(-1.98)$ & $(1.09)$ \\
\hline \multirow{2}{*}{ Lev } & -0.003 & $0.003^{* * *}$ \\
& $(-1.58)$ & $(8.84)$ \\
\hline \multirow{2}{*}{ Roa } & $0.031^{* * *}$ & $0.015^{* * *}$ \\
& $(2.81)$ & $(7.65)$ \\
\hline \multirow{2}{*}{ Growth } & -0.037 & $0.026^{* * *}$ \\
& $(-0.91)$ & $(3.73)$ \\
\hline \multirow{2}{*}{ Dual } & $0.108^{* * *}$ & $\left(-0.008^{* * *}\right.$ \\
& $(15.42)$ & -0.000 \\
\hline \multirow{2}{*}{ Board } & 0.004 & $(-0.54)$ \\
& $(1.02)$ & $0.001^{* *}$ \\
\hline
\end{tabular}


Table 9. Cont.

\begin{tabular}{ccc}
\hline & $\mathbf{( 1 )}$ & $\mathbf{( 2 )}$ \\
\cline { 2 - 3 } & Overinvest & Underinvest \\
\hline \multirow{2}{*}{ Indr } & $\begin{array}{c}-0.010 \\
(-0.27)\end{array}$ & -0.003 \\
& -0.001 & $-0.47)$ \\
\hline \multirow{2}{*}{ First } & $(-0.09)$ & $(-0.01)$ \\
\hline \multirow{2}{*}{ Mkt } & -0.002 & 0.000 \\
Year\&Industry & $(-1.59)$ & $(0.26)$ \\
\hline \multirow{2}{*}{ cons } & Control & Control \\
\hline N & $0.142 * * *$ & $-0.128 * * *$ \\
\hline r2_a & $(3.23)$ & $(-15.31)$ \\
\hline
\end{tabular}

Note: ${ }^{* * *}, * *$ and ${ }^{*}$ represent significance levels of $1 \%, 5 \%$ and $10 \%$, respectively.

Table 10. Mediation effect testing of enterprise financing.

\begin{tabular}{|c|c|c|}
\hline & (1) & (2) \\
\hline & Overinvest & Overinvest \\
\hline Pollute & $\begin{array}{l}-0.037 \\
(-0.42)\end{array}$ & $\begin{array}{l}-0.032 \\
(-0.36)\end{array}$ \\
\hline Regulation & $\begin{array}{c}0.027 * * * \\
(3.83)\end{array}$ & $\begin{array}{c}0.028^{* * *} \\
(4.05)\end{array}$ \\
\hline Pollute_Regulation & $\begin{array}{l}-0.013 * \\
(-1.91)\end{array}$ & $\begin{array}{l}-0.010 \\
(-1.42)\end{array}$ \\
\hline Debt & $\begin{array}{c}0.032 * \\
(1.76)\end{array}$ & \\
\hline Long_loan & & $\begin{array}{c}0.188 * * * \\
(6.86)\end{array}$ \\
\hline Size & $\begin{array}{l}-0.003 \\
(-1.64)\end{array}$ & $\begin{array}{c}-0.006^{* * *} \\
(-3.07)\end{array}$ \\
\hline Lev & $\begin{array}{l}0.014 \\
(0.98) \\
\end{array}$ & $\begin{array}{l}0.009 \\
(0.79)\end{array}$ \\
\hline Roa & $\begin{array}{l}-0.026 \\
(-0.62)\end{array}$ & $\begin{array}{l}-0.008 \\
(-0.20)\end{array}$ \\
\hline Growth & $\begin{array}{c}0.108^{* * *} \\
(15.44)\end{array}$ & $\begin{array}{c}0.108^{* * *} \\
(15.50)\end{array}$ \\
\hline Dual & $\begin{array}{l}0.004 \\
(0.94)\end{array}$ & $\begin{array}{l}0.004 \\
(1.05)\end{array}$ \\
\hline Board & $\begin{array}{c}-0.003^{* * *} \\
(-2.89)\end{array}$ & $\begin{array}{c}-0.003^{* * *} \\
(-2.59)\end{array}$ \\
\hline Indr & $\begin{array}{l}-0.009 \\
(-0.26)\end{array}$ & $\begin{array}{l}-0.002 \\
(-0.07)\end{array}$ \\
\hline First & $\begin{array}{l}-0.000 \\
(-0.02)\end{array}$ & $\begin{array}{l}-0.000 \\
(-0.01)\end{array}$ \\
\hline Mkt & $\begin{array}{l}-0.002 \\
(-1.57)\end{array}$ & $\begin{array}{l}-0.001 \\
(-0.89)\end{array}$ \\
\hline Year\&Industry & Control & Control \\
\hline _cons & $\begin{array}{c}0.144^{* * *} \\
(3.28)\end{array}$ & $\begin{array}{c}0.188^{* * *} \\
(4.25)\end{array}$ \\
\hline $\mathrm{N}$ & 2899.000 & 2899.000 \\
\hline r2_a & 0.123 & 0.137 \\
\hline
\end{tabular}

Note: ${ }^{* * *}, * *$ and ${ }^{*}$ represent significance levels of $1 \%, 5 \%$ and $10 \%$, respectively. 
Environmental Regulation and Corporate Value Analysis

As the most basic financial activity of an enterprise, investment is not only the most important factor in creating enterprise value, but it is also an important factor affecting macroeconomic operations and the capital market. When environmental regulations are upgraded, the financing behaviors of heavily polluting enterprises are limited, and their investment opportunities are affected by the mediating effects. However, when the investment opportunities of heavily polluting enterprises are inhibited, has corporate value, as the ultimate manifestation of the economic consequences of the enterprise, been compromised? Table 11 shows the results for environmental regulation and corporate values. In column (1), no control variables are added, and Pollute_Regulation is negatively significant at the $1 \%$ level, while in column (2), Pollute_Regulationhas the same coefficient of $-0,418$, which again is significantly negative at the $1 \%$ level compared with non-heavily polluting enterprises (control group). The value of firms in heavily polluting enterprises (experimental group) decreased by $41.8 \%$ after the promulgation of the new Environmental Protection Law. After adding the company-level control variable, compared with the model before the control variable was added, the model interpretation R-squared is significantly improved. This result indicates that after the establishment of the new Environmental Protection Law, heavily polluting enterprises faced more severe regulatory pressures and social public pressures. The pressures affect the investment and financing behaviors of enterprises and ultimately reduce their value.

Table 11. Environmental regulation and corporate values.

\begin{tabular}{|c|c|c|}
\hline & (1) & (2) \\
\hline & Tobin & Tobin \\
\hline Pollute & $\begin{array}{c}-0.502^{* * *} \\
(-8.75)\end{array}$ & $\begin{array}{c}0.899 * * * \\
(3.09)\end{array}$ \\
\hline Regulation & $\begin{array}{c}1.045^{* * *} \\
(23.11)\end{array}$ & $\begin{array}{c}1.547^{* * *} \\
(27.09)\end{array}$ \\
\hline Pollute_Regulation & $\begin{array}{c}-0.291 * * * \\
(-3.60)\end{array}$ & $\begin{array}{c}-0.418^{* * *} \\
(-6.85)\end{array}$ \\
\hline Size & & $\begin{array}{c}-0.874 * * * \\
(-55.72) \\
\end{array}$ \\
\hline Lev & & $\begin{array}{l}-0.055 \\
(-0.61)\end{array}$ \\
\hline Roa & & $\begin{array}{c}7.930 * * * \\
(24.37)\end{array}$ \\
\hline Growth & & $\begin{array}{c}-0.277^{* * *} \\
(-4.60)\end{array}$ \\
\hline Dual & & $\begin{array}{l}0.019 \\
(0.57)\end{array}$ \\
\hline Board & & $\begin{array}{c}0.023^{* *} \\
(2.24)\end{array}$ \\
\hline Indr & & $\begin{array}{c}1.690^{* * *} \\
(5.39)\end{array}$ \\
\hline First & & $\begin{array}{c}0.283^{* * *} \\
(2.72)\end{array}$ \\
\hline Mkt & & $\begin{array}{l}-0.002 \\
(-0.20)\end{array}$ \\
\hline Year\&Industry & & Control \\
\hline _cons & $\begin{array}{c}1.875^{* * *} \\
(57.89)\end{array}$ & $\begin{array}{c}19.665^{* * * *} \\
(52.58)\end{array}$ \\
\hline $\mathrm{N}$ & 9018.000 & 8954.000 \\
\hline r2_a & 0.093 & 0.486 \\
\hline
\end{tabular}

Note: ${ }^{* * * * *}$ and ${ }^{*}$ represent significance levels of $1 \%, 5 \%$ and $10 \%$, respectively. 


\subsection{Robustness Testing}

\subsubsection{Replacing Variables}

To ensure the robustness of the results, the robustness of the whole sample is tested. The paper replaces the explained variables using the asset-liability ratio (Lev), the bank borrowings to total debt ratio (Debt1), and the (long-term borrowings + short-term borrowings) to total assets ratio (long_debt) as proxy variables for the corporate financing capacity in robustness testing. The results show that after replacing the explained variables, environmental regulation still has a significant negative net effect on the financing ability of heavily polluting enterprises. Pollute_Regulation is significantly negative in columns (1), (2) and (3) of Table 12. The coefficients are $-0.012,-0.018$ and -0.015 , respectively, indicating that compared with non-heavily polluting enterprises (control group), the heavily polluting enterprise proportion of debt financing decreased by $1.2 \%, 1.8 \%$, and $1.5 \%$, respectively, after the promulgation of the new Environmental Protection Law.

Table 12. Robustness testing by replacing variables.

\begin{tabular}{|c|c|c|c|}
\hline & (1) & (2) & (3) \\
\hline & Lev & Debt1 & Debt2 \\
\hline Pollute & $\begin{array}{l}0.038 \\
(0.72)\end{array}$ & $\begin{array}{c}0.149^{* *} \\
(2.07)\end{array}$ & $\begin{array}{l}0.065^{*} \\
(1.74)\end{array}$ \\
\hline Regulation & $\begin{array}{c}-0.023^{* * *} \\
(-3.57)\end{array}$ & $\begin{array}{c}-0.033^{* * *} \\
(-3.74)\end{array}$ & $\begin{array}{c}-0.026^{* * *} \\
(-5.68)\end{array}$ \\
\hline Pollute_Regulation & $\begin{array}{l}-0.012 * \\
(-1.73)\end{array}$ & $\begin{array}{l}-0.018^{*} \\
(-1.84)\end{array}$ & $\begin{array}{c}-0.015^{* * *} \\
(-2.97)\end{array}$ \\
\hline Size & $\begin{array}{c}0.075^{* * *} \\
(45.59)\end{array}$ & $\begin{array}{c}0.044^{* * *} \\
(19.49)\end{array}$ & $\begin{array}{c}0.034^{* * *} \\
(29.28)\end{array}$ \\
\hline Roa & $\begin{array}{c}-1.583^{* * *} \\
(-46.78)\end{array}$ & $\begin{array}{c}-1.329 * * * \\
(-28.84)\end{array}$ & $\begin{array}{c}-0.995^{* * *} \\
(-41.60)\end{array}$ \\
\hline Growth & $\begin{array}{c}0.063^{* * *} \\
(9.06)\end{array}$ & $\begin{array}{c}0.069 * * * \\
(7.29)\end{array}$ & $\begin{array}{c}0.045^{* * *} \\
(9.14)\end{array}$ \\
\hline Dual & $\begin{array}{c}-0.016^{* * *} \\
(-4.03)\end{array}$ & $\begin{array}{l}0.005 \\
(0.92)\end{array}$ & $\begin{array}{l}0.001 \\
(0.53)\end{array}$ \\
\hline Board & $\begin{array}{c}0.003^{* * *} \\
(2.75)\end{array}$ & $\begin{array}{l}0.003 * \\
(1.86)\end{array}$ & $\begin{array}{c}0.003^{* * *} \\
(2.90)\end{array}$ \\
\hline Indr & $\begin{array}{l}0.008 \\
(0.23)\end{array}$ & $\begin{array}{c}0.128^{* *} \\
(2.56)\end{array}$ & $\begin{array}{l}0.044^{*} \\
(1.70)\end{array}$ \\
\hline First & $\begin{array}{c}-0.057^{* * *} \\
(-4.67)\end{array}$ & $\begin{array}{c}-0.095^{* * *} \\
(-5.71)\end{array}$ & $\begin{array}{c}-0.038^{* * *} \\
(-4.43)\end{array}$ \\
\hline \multirow[t]{2}{*}{ Mkt } & $\begin{array}{c}-0.010^{* * *} \\
(-9.18)\end{array}$ & $\begin{array}{c}-0.005^{* * *} \\
(-3.56)\end{array}$ & $\begin{array}{c}-0.004^{* * *} \\
(-5.16)\end{array}$ \\
\hline & (2.69) & (2.41) & (2.63) \\
\hline _cons & $\begin{array}{c}-1.138^{* * *} \\
(-26.95)\end{array}$ & $\begin{array}{c}-0.560^{* * *} \\
(-9.73)\end{array}$ & $\begin{array}{c}-0.578^{* * *} \\
(-19.35)\end{array}$ \\
\hline $\mathrm{N}$ & 9309.000 & 9309.000 & 9309.000 \\
\hline r2_a & 0.417 & 0.241 & 0.353 \\
\hline
\end{tabular}

Note: ${ }^{* * *}, * *$ and ${ }^{*}$ represent significance levels of $1 \%, 5 \%$ and $10 \%$, respectively.

\subsubsection{Fixed Effect Regression + Bootstrap Self-Sampling Method}

This article also uses fixed effect regression and the bootstrap self-sampling method for robustness tests. Table 13 reverifies the results of the above hybrid model. The fixed effect regression results of columns (1), (2), (3) and (4) indicate that the Regulation variable has a significant, negative relationship with Long_loan and Debt for both the experimental group and the control group. However, for the heavily polluting enterprises in the experimental group, the coefficients of Regulation $(-0.045$ and $-0.020)$ were much smaller than those of the control group ( -0.022 and -0.004$)$. Referring to the 
methods of Cleary [38] and Lian et al. [39], the paper uses the "self-sampling method" (bootstrapping) to test the difference between the coefficients of the groups. The original hypothesis of this method is that the coefficient difference $d=0$ randomly selects $n 1$ and $n 2$ enterprises from the original $n$ sample enterprises and assigns them to the experimental group and the control group, respectively; it estimates the coefficient values in the two groups and records the coefficient difference di and then repeats the above steps $\mathrm{K}$ times ( $\mathrm{K}=300$ in this paper). Next, it calculates the percentage of di $(\mathrm{i}=1$, $2, \ldots, \mathrm{k}$ ) greater than the estimated difference d (i.e., 0 ), that is, the $p$-value of the last row of Table 10. The empirical $p$-values of the difference in the Regulation coefficient in columns (1) and (2) in the study are 0.007 and 0.02 , respectively, which are significant at the $1 \%$ level. This finding indicated that after the promulgation of new Environmental Protection Law, heavily polluting enterprises' bank loans decreased by $4.5 \%$, and long-term loans decreased by $2 \%$. Thus, for the heavily polluting enterprises in the experimental group, the negative impact of environmental regulation on the scale of corporate financing is more obvious. Columns (3) and (4) use the long-term borrowing ratio (Long_loan) as the explanatory variable and conclude that the coefficient of the experimental group is smaller than the coefficient of the control group, and the empirical $p$-value is significant at the $1 \%$ level. Environmental regulation has a far-reaching, negative impact on the debt structure of heavily polluting enterprises.

Table 13. Bootstrapping.

\begin{tabular}{|c|c|c|c|c|}
\hline & (1) & (2) & (3) & (4) \\
\hline & Experimental & Control & Experimental & Control \\
\hline & Debt & Debt & Long_loan & Long_loan \\
\hline Regulation & $\begin{array}{c}-0.045^{* * *} \\
(-6.47)\end{array}$ & $\begin{array}{c}-0.022 * * * \\
(-5.15)\end{array}$ & $\begin{array}{c}-0.020^{* * *} \\
(-4.30)\end{array}$ & $\begin{array}{l}-0.004 * \\
(-1.66)\end{array}$ \\
\hline Size & $\begin{array}{c}0.020^{* * *} \\
(10.23)\end{array}$ & $\begin{array}{l}-0.002 * \\
(-1.89) \\
\end{array}$ & $\begin{array}{c}0.021^{* * *} \\
(16.19) \\
\end{array}$ & $\begin{array}{c}0.007^{* * *} \\
(11.22) \\
\end{array}$ \\
\hline Lev & $\begin{array}{c}0.534^{* * *} \\
(47.14)\end{array}$ & $\begin{array}{c}0.442^{* * *} \\
(61.28) \\
\end{array}$ & $\begin{array}{c}0.117^{* * *} \\
(15.45)\end{array}$ & $\begin{array}{c}0.077^{* * *} \\
(21.16)\end{array}$ \\
\hline Roa & $\begin{array}{c}-0.209 * * * \\
(-5.22) \\
\end{array}$ & $\begin{array}{c}-0.371^{* * *} \\
(-13.99) \\
\end{array}$ & $\begin{array}{l}-0.011 \\
(-0.40)\end{array}$ & $\begin{array}{c}-0.116^{* * *} \\
(-8.71)\end{array}$ \\
\hline Growth & $\begin{array}{l}0.007 \\
(0.93)\end{array}$ & $\begin{array}{c}0.015^{* * *} \\
(2.98)\end{array}$ & $\begin{array}{l}0.005 \\
(1.09)\end{array}$ & $\begin{array}{c}0.009^{* * *} \\
(3.54)\end{array}$ \\
\hline Dual & $\begin{array}{l}0.004 \\
(0.87) \\
\end{array}$ & $\begin{array}{c}0.009^{* * *} \\
(3.50)\end{array}$ & $\begin{array}{l}-0.005 \\
(-1.55)\end{array}$ & $\begin{array}{l}-0.000 \\
(-0.26)\end{array}$ \\
\hline Board & $\begin{array}{c}0.004^{* * *} \\
(2.73)\end{array}$ & $\begin{array}{l}0.000 \\
(0.22) \\
\end{array}$ & $\begin{array}{l}-0.000 \\
(-0.27)\end{array}$ & $\begin{array}{c}-0.002 * * * \\
(-4.15)\end{array}$ \\
\hline Indr & $\begin{array}{l}0.035 \\
(0.82) \\
\end{array}$ & $\begin{array}{c}0.054^{* *} \\
(2.19)\end{array}$ & $\begin{array}{l}-0.003 \\
(-0.11) \\
\end{array}$ & $\begin{array}{c}-0.024^{* *} \\
(-1.96)\end{array}$ \\
\hline First & $\begin{array}{l}0.014 \\
(1.01) \\
\end{array}$ & $\begin{array}{c}-0.042 * * * \\
(-5.05)\end{array}$ & $\begin{array}{l}0.011 \\
(1.16) \\
\end{array}$ & $\begin{array}{c}-0.019 * * * \\
(-4.46)\end{array}$ \\
\hline Mkt & $\begin{array}{l}0.000 \\
(0.10) \\
\end{array}$ & $\begin{array}{l}-0.000 \\
(-0.35) \\
\end{array}$ & $\begin{array}{c}-0.005^{* * *} \\
(-6.27) \\
\end{array}$ & $\begin{array}{c}-0.002 * * * \\
(-5.92) \\
\end{array}$ \\
\hline Year\&Industry & Control & Control & Control & Control \\
\hline _cons & $\begin{array}{c}-0.457^{* * *} \\
(-8.68)\end{array}$ & $\begin{array}{c}0.067^{* *} \\
(2.21) \\
\end{array}$ & $\begin{array}{c}-0.413^{* * *} \\
(-11.74)\end{array}$ & $\begin{array}{c}-0.065^{* * *} \\
(-4.30)\end{array}$ \\
\hline $\mathrm{N}$ & 2918.000 & 6391.000 & 2918.000 & 6391.000 \\
\hline r2_a & 0.664 & 0.540 & 0.492 & 0.262 \\
\hline$p$-value & 0.007 & & 0.002 & \\
\hline
\end{tabular}

Placebo Testing

It is doubtful that the significance of the treatment effect from the establishment of the new Environmental Protection Law has no meaning, that is, that this result could exist in any year and could be affected by sample selection or overall time trend. To exclude the above possibility, the 
researchers used the placebo test method based on the research design of Gan [40] and Butler et al. [41]. First, the study set a dummy year point before the actual year in which the new Environmental Protection Act was promulgated as a placebo test. If there is a causal effect between environmental regulation and the financing ability of heavily polluting enterprises, then if the event did not happen, the processing effect of the virtual new Environmental Protection Law cannot theoretically be observed. The Pollute_Regulation coefficient should no longer be negatively significant, and if its negative significance persists in the placebo test, then the previous estimates are meaningless. The detailed research design is as follows. The article defines a time point for the promulgation of the new Environmental Protection Law in 2012 as two years in advance and obtains relevant data for the first three years and the last three years (including the event year), for a total of six years. In Table 14, the results show that the coefficient of Pollute_Regulation is small and no longer significant, whether Debt or Long_loan represents financing ability, and the dummy time points no longer have a negative net effect on heavily polluting enterprise financing. This finding indicates that the study passed the placebo test. With the upgrading of the new Environmental Protection Law, the legislation and law enforcement supporting environmental protection have made significant progress. The concept of "green" and sustainable development has gradually become a core concept of the Chinese government in economic construction, and the empirical results of this paper also reflect this concept from the perspective of corporate financing.

Table 14. Placebo testing.

\begin{tabular}{|c|c|c|}
\hline & (1) & (2) \\
\hline & Debt & Long_loan \\
\hline Pollute & $\begin{array}{l}-0.001 \\
(-0.06)\end{array}$ & $\begin{array}{c}0.028 * * \\
(2.01)\end{array}$ \\
\hline Regulation & $\begin{array}{l}-0.008^{*} \\
(-1.69)\end{array}$ & $\begin{array}{c}-0.009^{* * *} \\
(-3.28)\end{array}$ \\
\hline Pollute_Regulation & $\begin{array}{l}-0.007 \\
(-1.38)\end{array}$ & $\begin{array}{l}-0.003 \\
(-0.93)\end{array}$ \\
\hline Size & $\begin{array}{c}0.010^{* * *} \\
(8.20)\end{array}$ & $\begin{array}{c}0.016^{* * *} \\
(21.83)\end{array}$ \\
\hline Lev & $\begin{array}{c}0.455^{* * *} \\
(67.82)\end{array}$ & $\begin{array}{c}0.082 * * * \\
(20.28)\end{array}$ \\
\hline Roa & $\begin{array}{c}-0.309^{* * *} \\
(-12.72)\end{array}$ & $\begin{array}{c}-0.086^{* * *} \\
(-5.86)\end{array}$ \\
\hline Growth & $\begin{array}{c}0.022^{* * *} \\
(4.52)\end{array}$ & $\begin{array}{c}0.013^{* * * *} \\
(4.33)\end{array}$ \\
\hline Dual & $\begin{array}{c}0.005^{*} \\
(1.74)\end{array}$ & $\begin{array}{l}-0.003 \\
(-1.46)\end{array}$ \\
\hline Board & $\begin{array}{l}0.001 \text { * } \\
(1.69)\end{array}$ & $\begin{array}{l}-0.001 \\
(-1.59)\end{array}$ \\
\hline Indr & $\begin{array}{l}0.009 \\
(0.36)\end{array}$ & $\begin{array}{l}-0.018 \\
(-1.15)\end{array}$ \\
\hline First & $\begin{array}{l}-0.015^{*} \\
(-1.80)\end{array}$ & $\begin{array}{l}-0.009 * \\
(-1.72)\end{array}$ \\
\hline Mkt & $\begin{array}{l}-0.000 \\
(-0.46)\end{array}$ & $\begin{array}{c}-0.005^{* * *} \\
(-10.97)\end{array}$ \\
\hline Year\&Industry & Control & Control \\
\hline _cons & $\begin{array}{c}-0.251^{* * *} \\
(-8.46)\end{array}$ & $\begin{array}{c}-0.262^{* * *} \\
(-14.71)\end{array}$ \\
\hline $\mathrm{N}$ & 7913.000 & 7913.000 \\
\hline r2_a & 0.611 & 0.424 \\
\hline
\end{tabular}

Note: ${ }^{* * *}, * *$ and $*$ represent significance levels of $1 \%, 5 \%$ and $10 \%$, respectively. 


\section{Conclusions and Discussion}

China's economy has entered a period characterized by a new normal; under this new normal, it is critical that China continue industrial deepening and accelerate industrial development (in December 2014, the Central Economic Work Conference pointed out that the Chinese economy is in the middle of a new transformation marked by a new normal of moderated growth speed, improved structure, and the rise of new drivers of growth). However, the perspective of GDP supremacy is no longer in line with the concept of economically sustainable development. Against the background of constructing an ecological civilization, environmental issues have become particularly important. This paper, considering environmental governance under the new normal in China, uses the promulgation of the new Environmental Protection Law as a quasi-natural experiment and the DID model to test the impact of environmental regulation on corporate financing. The results of this empirical research show that after the establishment of the new Environmental Protection Law, the business risk presented by heavily polluting enterprises suddenly increased, as heavily polluting enterprises faced stricter environmental regulations and paid higher costs for polluting the environment in terms of external financing. The cost is specifically reflected in the reduction in bank borrowing and the shortening of the debt maturity, and this negative net effect is more pronounced in areas with higher-intensity environmental regulation. In further research, this paper finds that the upgrading of environmental regulation inhibits the investment behaviors of heavily polluting enterprises and reduces the value of enterprises by affecting financing through intermediary variables. The research in this paper is helpful for understanding corporate financing behavior given the background of China's environmental governance and the framework of the formal system, and it could help authorities to find new solutions to increase the effectiveness of environmental governance.

In addition to the theoretical research contributions to the areas of rich environmental regulation and corporate finance, this study also has certain practical implications. First, commercial banks are the main type of finance providers in China; before agreeing to extend loans to heavily polluting enterprises, they should adopt more rigorous environmental auditing. If a company engages in polluting behavior, it should find it difficult to obtain financing. The empirical results of this paper confirm that heavily polluting enterprises are constrained in their debt financing, indicating that China's Green Credit policy has become an important criterion for banks making loan decisions. Second, in the process of environmental protection, heavily polluting enterprises should fulfill their obligations. Media reports and public participation should also play active supervisory roles: they should not only supervise the behavior of heavily polluting enterprises but also expose the government's collusion with polluting enterprises. Therefore, environmental regulation should the main driving force enhancing an enterprise's environmental behavior norms. In the past, China's heavily polluting enterprises belonged to groups with political advantages. They often obtained policy inclinations in debt financing. Under the new Environmental Protection Law, the research results could cause the management of China's heavily polluting enterprises to realize that it can no longer develop as at first and then reduce pollution. If it does not reduce pollution, it will not receive sufficient government support, with the final result of a decline in the value of the company. The research structure of this paper helps to deepen the understanding of the effect of the implementation of the new Environmental Protection Law and has certain practical guiding significance for understanding the transformation and upgrading of the heavily polluting enterprises at the micro level. At the same time, the research in this paper can expand the understanding of the effect of corporate governance on debt.

There are still limitations to this study. First, the article uses the promulgation of the new Environmental Protection Law as a time point to measure changes in environmental regulation and to test and analyze its impact on the financing of heavily polluting enterprises; however, the data might be affected by noise caused by the effect of mixing. This problem is difficult to overcome in empirical research. However, through the institutional background analysis and robustness testing, we believe that the distinction between the period before the new Environmental Protection Law went into effect and after it can represent a major environmental regulation upgrade, which can rationally 
support the empirical design. Second, this paper studies the impact of environmental regulation on the financing of heavily polluting enterprises but does not consider the heterogeneity of heavily polluting enterprises, such as political relations, environmental information disclosure and social responsibility performance's impact on corporate financing. Other researchers should further study these issues. Third, after the promulgation of the new Environmental Protection Law, to encourage social development under the new normal, it is necessary to accurately locate the relationship between economic development and environmental protection. The escalation of regulatory conditions has a far-reaching impact on heavily polluting enterprises not limited to corporate financing behavior but also impacting corporate risk, corporate strategic policies, corporate investment behavior and corporate social responsibility. All of the above could be the topics of future research.

Author Contributions: X.L. and E.W. worded collectively and equally contributed to this paper. X.L. and E.W. conceived of and structured the paper, performed the data analyses, wrote drafting and revising the manuscript together. D.C. made valuable suggestions and was responsible for some data collection. All of the authors read and approved the submission.

Funding: This research received no external funding.

Acknowledgments: We would like to thank the editor and three anonymous reviewers for worthy comments and suggestions that improved the article.

Conflicts of Interest: The authors declare no conflict of interest.

\section{References}

1. Testa, I.F. The effect of environment regulation on firm's competitive performance. J. Environ. Manag. 2011, 92, 2136-2144. [CrossRef] [PubMed]

2. Gollop, F.M.; Roberts, M.J. Environmental Regulations and Productivity Growth: The Case of Fossil-fueled Electric Power Generation. J. Political Econ. 1983, 91, 654-657. [CrossRef]

3. Gray, R.; Kouhy, R.; Lavers, S. Corporate social and environmental reporting: A review of the literature and a longitudinal study of UK disclosure. Account. Audit. Account. J. 1985, 8, 47-77. [CrossRef]

4. Barbera, A.J.; McConnell, V.D. The impact of environment regulations on industry productivity: Direct and indirect effects. J. Environ. Econ. Manag. 1990, 18, 50-65. [CrossRef]

5. Porter, M.E. Towards A Dynamic Theory of Strategy. Strategy Manag. J. 1991, 12, 95-117. [CrossRef]

6. Porter, M.E.; Van der Linde, C. Toward a New Conception of the Environment Competitiveness Relationship. J. Econ. Perspect. 1995, 9, 97-118. [CrossRef]

7. Zhang, S.F.; Bu, M.L. Environment Regulaton, Environmental Protection Investment and Productivity. Nankai Econ. Stud. 2011, 2, 129-146. (In Chinese)

8. Lanoie, P.L. Environmental regulation and productivity: Testing the Porter hypothesis. J. Prod. Anal. 2008, 30, 121-128. [CrossRef]

9. Shleifer, A.; Vishny, R.W. A Survey of Corporate Governance. J. Financ. 1997, 52, 753-754. [CrossRef]

10. Jensen, M.C.; Meckling, W.H. Theory of firm: Managerial behavior, agency cost and ownership structure. J. Financ. Econ. 1976, 3, 305-360. [CrossRef]

11. Servas, H. The Value of Diversification during the Conglomerate Merge Wave. J. Financ. 1996, 51, 1201-1225. [CrossRef]

12. Graham, J.; Lemmon, M.; Wolf, J. Does Corporate Diversification Destroy Value? J. Financ. 2002, 2, 695-720. [CrossRef]

13. Zhang, G.W.; Zhang, W.F. Profitability. Environmental Enforcement and the Share Price Response to Environmental Law based on the release of "The New Environmental Protection Law". J. Guizhou Univ. Financ. Econ. 2017, 1, 59-69. (In Chinese)

14. Ji, L.; Wang, T.W.; Wei, J. The Insurance like Effect of Corporate Social Responsibility: An Event Study on the Promulgation of the New Environmental Protection Law. J. Account. Econ. 2018, 32, 21-37. (In Chinese)

15. Green, A. You can't pay them enough: Subsidies, Environment Law, and Social Norms. Harvard Environ. Law Rev. 2006, 3, 407-426.

16. Coffee, J.C. Do Norms Matter? A Cross-Country Examination of the private Benefits of Control; University of Pennsylvania Law Review: Philadelphia, PA, USA, 2001; p. 149. Available online: https:/ /www.jstor.org/ stable/3312908 (accessed on 9 September 2018). 
17. Schneider, T.E. Is There a Relation between the Cost of Debt and Environmental Performance? An Empirical Investigation of the U. S. Pulp and Paper Industry. Ph.D. Thesis, University of Waterloo, Waterloo, ON, Canada, 2008.

18. Liu, X.H. Public pressure, property right and corporate financing-Based on the study of "PM2.5 explosion incident". Econ. Sci. 2016, 2, 67-80. (In Chinese)

19. Stiglitz, J.E.; Weiss, A. Credit Rationing in Markets with Imperfect Information. Am. Econ. Rev. 1981, 71, $393-410$.

20. Axelrod, R. An Evolutionary Approach to Norms. Am. Political Sci. Rev. 1986, 80, 1095-1111. [CrossRef]

21. Zhou, L.A. Governing China's Local Officials: An Analysis of Promotion Tournament Model. Econ. Res. J. 2007, 7, 36-50. (In Chinese)

22. Faccio, M. Politically-Connected Firms: Can the Squeeze the State. Social. Sci. Electronic. Publishing. 2006, 96, 369-386. [CrossRef]

23. La Porta, R.; Lopez-de-Silanes, F.; Shleifer, A.; Vishny, R. Government Ownership of Banks. J. Financ. 2002, 57, 265-301. [CrossRef]

24. Giannetti, M. Do Better Institutions Mitigate Agency Problems? Evidence from Corporate Finance Choices. J. Financ. Quant. Anal. 2003, 38, 185-212. [CrossRef]

25. Fan, J.P.H.; Titman, S.; Twite, G. An International Comparison of Capital Structure and Debt Maturity Choice. J. Financ. Quant. Anal. 2012, 47, 23-56. [CrossRef]

26. Wang, X.L.; Fan, G.; Yu, J. Marketization Index of China's Provence: NERI Report 2016, 1st ed.; Social Science Academic Press: Beijing, China, 2017. (In Chinese)

27. Tang, G.P.; Li, L.H.; Wu, D.J. Environmental Regulation, Industry Attributes and Corporate Environmental Investment. Account. Res. 2013, 6, 83-96. (In Chinese)

28. Shen, H.T.; Ma, Z.B. Local Economic Development Pressure, Firm Environmental Performance and Debt Financing. J. Financ. Res. 2014, 2, 153-166. (In Chinese)

29. Bertrant, M.; Mullainathan, S. Enjoying the quite life? Corporate governance and managerial preferences. J. Political Econ. 2003, 5, 1043-1075. [CrossRef]

30. Ye, Q.; Li, Z.Q.; Li, G.Q. The rich list will affect the quality of accounting information? Manag. World 2012, 1, 104-120. (In Chinese)

31. Liu, Y.G.; Liu, M.N. Have Smog Affected Earning Management of Heavily polluting Enterprises?-Based on the Political-Cost Hypothesis. Account. Res. 2015, 3, 26-33. (In Chinese)

32. Zhu, J.G.; Han, F.C.; Lu, Z.F. Industry Policy, Bank Connections, and Debt Financing: An Empirical Research Based on A-share Listed Companies. J. Financ. Res. 2015, 3, 176-191. (In Chinese)

33. Zhong, K.; Cheng, X.K.; Zhang, W.G. The Moderate Adjustment of Monetary Policy and the Phenomenon of Corporate Long-term Investment with Short-term Financing. Manag. World 2016, 3, 87-114. (In Chinese)

34. Li, W.J.; Lu, X.Y. Institutional Interest, Ownership Type, and Environmental Capital Expenditures: Evidence from the Most Polluting Chinese Listed Firms. J. Bus. Ethics 2016, 3, 459-476. [CrossRef]

35. La Porta, R.; Lopez de Silanes, F.; Shleifer, A.; Vishny, R.W. Law and Finance. J. Political Econ. 1998, 106, 1113-1155. [CrossRef]

36. Fazzari, S.M.; Hubbard, R.G.; Petersen, B.C. Financing constraints and corporate investment. Brook. Pap. Econ. Act. 1988, 1, 141-206. [CrossRef]

37. Richardson, S. Over-Investment of Free Cash Flow. Rev. Account. 2006, 11, 159-189. [CrossRef]

38. Cleary, S. The Relationship between Firm Investment and Financial Status. J. Financ. 1999, 54, 673-692. [CrossRef]

39. Lian, Y.J.; Cheng, J. Investment-Cash Flow Sensitivity: Financial Constraints or Agency Costs? J. Financ. Econ. 2007, 2, 37-46. (In Chinese)

40. Gan, J.B.; McCarl, B.A. Measuring transnational leakage of forest conservation. Ecol. Econ. 2007, 64, 423-432. [CrossRef]

41. Butler, A.W.; Cornaggia, J. Does access to external finance improve productivity? Evidence from a natural experiment. J. Financ. Econ. 2011, 99, 184-203. [CrossRef]

(C) 2018 by the authors. Licensee MDPI, Basel, Switzerland. This article is an open access article distributed under the terms and conditions of the Creative Commons Attribution (CC BY) license (http:/ / creativecommons.org/licenses/by/4.0/). 